\title{
Introduction to the Special Issue on Blended and Distance Learning for P-12 Contexts
}

\author{
Kalianne L. Neumann ${ }^{1}$ - Cecil R. Short ${ }^{2}$. Jacob A. Hall ${ }^{3}$. Frances Alvarado-Albertorio ${ }^{1}$ \\ Published online: 27 October 2021 \\ (c) Association for Educational Communications \& Technology 2021
}

As a result of increased access to technology and technological innovations designed to support teaching and learning, P-12 contexts have changed dramatically over the last decade. Papert (1984) predicted technology, specifically computers, would transform learning in the 1990s; however, it was not until the early 2010s when more ubiquitous technology access resulted in a dramatic transformation of the P-12 educational landscape, quickly surpassing what scholars and early innovators envisioned (Johnson et al., 2015). At the same time, P-12 online schools began growing in popularity and reach, with an increasing number of online schools operated by nonprofit corporations, public or private charter schools, states, and school districts - making online teaching and learning more accessible to those interested in alternative options (Gulosino \& Miron, 2017). In addition to this rise in $\mathrm{P}-12$ online schools, there was also a growth in P-12 blended learning as full-time blended learning programs began to emerge (Molnar et al., 2017) and individual teachers, schools, and districts began to implement blended learning pedagogies - though this growth was harder to measure (Graham, 2019).

However, more access to devices, educational applications, and online schooling options did not (and does not) automatically result in effective implementation and/or improved learning outcomes (Barbour, 2017). Scholars,

Kalianne L. Neumann

kalianne.neumann@okstate.edu

Cecil R. Short

cecil.r.short@gmail.com

Jacob A. Hall

jacob.hall@cortland.edu

Frances Alvarado-Albertorio

falvara@okstate.edu

1 Oklahoma State University, Stillwater, OK, USA

2 Texas Tech University, Lubbock, TX, USA

3 SUNY Cortland, Cortland, NY, USA teacher educators, and teachers have responded to dramatic changes in how P-12 instruction can be delivered by designing courses, professional development, and other initiatives to prepare P-12 teachers and students for blended and distance learning. Despite these efforts, many P-12 teachers, students, and families were unprepared to use blended and distance learning strategies during the abrupt transition to emergency remote teaching in Spring 2020 due to the COVID-19 pandemic (Hodges et al., 2020). Despite the chaos of emergency remote teaching that occurred during the period of pandemic teaching, we feel that it is important to recognize the P-12 distance and blended learning efforts that were ongoing before the pandemic and will continue long after it.

In an effort to share what is possible when it comes to preparing preservice and inservice teachers for distance and blended teaching and learning, the Teacher Education Division of the Association of Educational Communications and Technology sought original empirical, conceptual, and/or theoretical papers about blended and/or distance learning for P-12 contexts. Included in this issue are two columns and nine manuscripts that collectively demonstrate the past and future of distance and blended learning in P-12 schools. There are two invited columns: one from Michael K. Barbour about the rich history of P-12 distance learning in the United States and one from Carmen Richardson, Punya Mishra, and Danah Henriksen in which they interview Dr. Leanna Archambault to understand her views on the future of online learning and teacher preparation in the United States. The columns are followed by three original papers about P-12 distance teaching that focus on teaching practices that emerged during emergency remote teaching and one original paper about preparing preservice teachers for virtual student teaching. A paper describing a framework for evaluating online and blended instructional materials bridges the issue's focus on P-12 distance and blended learning. Following this framework, the issue begins its focus on blended learning for P-12 contexts with a systematic literature review 
on preparing K-12 teachers for blended teaching, two articles focused on preparing P-12 teachers for blended teaching, and a final paper concerning blended teaching practices in a secondary English course.

Michael K. Barbour's entry in the History Corner column highlights the rich history of K-12 distance learning in this issue's History Corner Column. As Barbour notes in his column, the history of K-12 distance learning predates the pandemic by over a century, providing teachers and teacher educators with plenty of opportunities to prepare for distance learning. Calls for such opportunities went largely unheeded in the United States, which led to the lack of preparedness that teachers, students, and families faced during the pandemic's period of emergency remote teaching.

In the Rethinking Technology \& Creativity in the 21st Century Column, Carmen Richardson, Punya Mishra, and Danah Henriksen interview Dr. Leanna Archambault, Associate Professor of Learning Design and Technology at Arizona State University, about creativity in online learning and teacher education. Archambault provides some optimistic views of the future of distance learning, noting that many teachers showed unprecedented creativity and resilience during the pandemic. She also provides foundational thoughts for the future of preparing teachers for distance (and inperson) teaching related to fostering teachers' instructional design skills and abilities to collaborate and work as part of a team of teachers with unified goals.

The original papers in this issue begin with Andrew A. Tawfik, Craig E. Shepherd, Jessica Gatewood, and Jaclyn J. Gish-Lieberman's investigation of how K-8 teachers at an inner-city school transitioned to online learning at the beginning of the COVID-19 school closings in Spring 2020. Using the lens of Ertmer's (1999) first- and second-order barriers, the authors identify the challenges, successes, lessons learned, and intentions of teachers to continue teaching with technology when in-person learning resumes.

Next, Yin-Chan (Janet) Liao, Anne Ottenbreit-Leftwich, Meina Zhu, Katie Jantaraweragul, Laura Christie, Kandi Krothe, and Katy Sparks share the perceptions and experiences of award-winning K-6 teachers to illustrate how we can support online instruction designed for elementary students. Their results further emphasize the importance of incorporating existing recommended practices when designing online instruction for elementary students (i.e., organization, student engagement, and variants of interaction). Moreover, the authors identify parental involvement and developmentally appropriate use of technology as instructional considerations shared by their participants that may be unique to supporting elementary students in fully online settings.

During the pandemic, P-12 teachers of all disciplines have found creative ways to support students' learning from a distance, and Peter Samuelson Wardrip, Kailea Saplan, and
Jeff Evancho uncover what assessment looks like in remote, maker-based learning activities. Using a values-based perspective, the authors describe how teachers adapted their pedagogical practice to facilitate maker-based learning at a distance by assessing emotional goals in addition to learning goals, asking students to document both their making process and products, and using low-tech rather than hightech tools. Not only do their findings highlight how teachers' pedagogical shifts ensured access and allowed students to develop digital portfolios, but also they describe how remote, maker-based instruction broadened teachers' learning goals and refocused their attention on how making could help students meet those learning goals.

While preparing preservice teachers' for online learning has been a persistent call in response to the growth of virtual enrollments and emergence of blended learning programs (Archambault et al., 2014; Ferdig et al., 2009; Molnar et al., 2017), the COVID-19 pandemic forced teacher educators to prepare preservice teachers in ways they had not previously. Jacob A. Hall, Christine Widdall, and Jing Lei present a design case that explores a course designed to prepare preservice teachers for virtual student teaching in Fall 2020. Basing their course design on the Presence + Experience Framework (Dunlap et al., 2016), the authors describe their design process and experiences using this framework to engage 237 preservice teachers during a 10-day online course. Their results suggest that the course supported preservice teachers' learning to teach online but also indicate the potential complexities of designing with the Presence + Experience Framework.

Bridging the special issue's focus on distance and blended learning, Mary Frances Rice and Kelsey R. Ortiz offer the 4A framework for evaluating digital instructional materials for K-12 online and blended learning, which includes four elements: Accessibility, Active Engagement, Advocacy for Inclusion, and Accountability. The authors document the development of this conceptual tool, detail each of its four elements, and offer vignettes to illustrate how $\mathrm{K}-12$ stakeholders may encounter and address issues with digital instructional materials. Their paper concludes with an extended checklist based on the framework that educators may use or customize when evaluating digital materials for online or blended settings.

Transitioning into the issue's focus on blended learning, Cecil R. Short, Charles R. Graham, Theresa Holmes, Laura Oviatt, and Hannah Bateman's systematic mapping literature review reveals research trends, impact, and themes of preparing teachers to teach in blended K-12 environments. Their research highlights the most impactful researchers in the area of K-12 blended teacher preparation, the most prevalent research methods in this field, and the most common publication venues for such research. They also provide an overview of research in $\mathrm{K}-12$ blended teacher preparation 
related to other reviews, models, and theories of K-12 blended learning; coursework and professional development opportunities used to promote blended teaching proficiency; competencies related to blended learning; and assessment and measurement tools for blended teaching readiness.

Sungwon Shin presents a design-based research project focused on partnering with content-specific teacher educators to create a program that would prepare teacher candidates for blended and personalized learning. Her research highlights the perceptions of teacher candidates and teacher educators surrounding the effectiveness of such a program. In her report, she provides insights concerning the design elements needed to create a program that specifically prepares $\mathrm{P}-12$ preservice teachers for the blended and personalized learning pedagogies that are in high demand from many P-12 schools.

To examine preservice teachers' potential to teach with technology in technology-rich and blended environments, Kalianne L. Neumann, Frances Alvarado-Albertorio, and Andrea Ramirez-Salgado study the effects of using Grossman et al.'s (2009) pedagogies of practice to design a standalone educational technology course. The course intentionally reflected the blended teaching practices seen in the university's placement school districts and engaged students in breaking down and experimenting with those teaching practices. The results suggest using the pedagogies of practice can positively impact preservice teachers' potential to teach with technology in technology-rich and blended environments.

The final original paper in the special issue, Elizabeth Florence and Tammi Kolski's action research illustrates the blended model of flipped learning in a high school English classroom. The authors investigate how using a flipped model impacts students' writing achievement, engagement, and perceptions. Students not only experienced writing achievement growth but also were more engaged and valued the self-directed learning afforded by the flipped approach.

While the COVID-19 pandemic underscored the need to prepare preservice and inservice teachers to teach in online and blended settings, we hope this special issue provides some insight into the blended and distance learning work that was happening in $\mathrm{P}-12$ contexts before and during the pandemic. Special thanks to Michael K. Barbour, Heather Leary, Barbara Lockee, Carmen Richardson, Punya Mishra, Danah Henriksen, and Leanna Archambault for answering our requests and working with us to include a History Corner Column and Rethinking Technology \& Creativity in the 21st Century Column that were thematically connected to our special issue. Additional thanks go out to all of the scholars who submitted proposals for the special issue as well as the authors who persevered through our thorough and specific feedback; two of us were former English teachers, and we know we were particular.

\section{References}

Archambault, L. M., DeBruler, K., \& Freidhoff, J. (2014). K-12 online and blended teacher licensure: Striking a balance between policy and preparedness. Journal of Technology and Teacher Education, 22(1), 83-106. https://www.learntechlib.org/primary/p/112361/

Barbour, M. K. (2017). K-12 online learning and school choice: Growth and expansion in the absence of evidence. In R. A. Fox \& N. K. Buchanan (Eds.), The Wiley Handbook of School Choice (pp. 421-440). John Wiley \& Sons Inc. https://doi.org/10.1002/97811 19082361.ch29

Dunlap, J. C., Verma, G., \& Johnson, H. L. (2016). Presence+experience: A framework for the purposeful design of presence in online courses. TechTrends, 60(2), 145-151. https:// doi.org/10.1007/s11528-016-0029-4

Ertmer, P. A. (1999). Addressing first- and second-order barriers to change: Strategies for technology integration. Educational Technology Research and Development, 47(4), 47-61. https://doi.org/ 10.1007/BF02299597

Ferdig, R. E., Cavanaugh, C., Dipietro, M., Black, E. W., \& Dawson, K. (2009). Virtual schooling standards and best practices for teacher education. Journal of Technology and Teacher Education, 17(4), 479-503. https://www.learntechlib.org/primary/p/30481/

Graham, C. R. (2019). Current research in blended learning. In M. G. Moore \& W. C. Diehl (Eds.), Handbook of Distance Education (4th ed., pp. 173-188). Routledge.

Grossman, P., Compton, C., Igra, D., Ronfeldt, M., Shahan, E., \& Williamson, P. (2009). Teaching practice: A cross-professional perspective. Teachers College Record, 111(9), 2055-2100. http:// www.tcrecord.org/Content.asp?ContentId $=15018$

Gulosino, C., \& Miron, G. (2017). Growth and performance of fully online and blended K-12 public schools. Education Policy Analysis Archives, 25(124), 1-43. https://doi.org/10.14507/epaa.25. 2859

Hodges, C.B., Moore, S., Lockee, B.B., Trust, T., \& Bond, M. A. (2020, March 27). The difference between emergency remote teaching and online learning. Educause Review. https://er.educause.edu/ articles/2020/3/the-difference-between-emergency-remote-teach ing-and-online-learning

Johnson, L., Adams Becker, S., Estrada, V., \& Freeman, A. (2015). NMC horizon report: $2015 \mathrm{~K}-12$ edition. The New Media Consortium

Molnar, A., Miron, G., Gulosino, C., Shank, C., Davidson, C., Barbour, M. K., Huerta, L., Shafer, S. R., Rice, J. K., \& Nitkin, D. (2017). Virtual Schools Report 2017. National Education Policy Center. http://nepc.colorado.edu/publication/virtual-schools-annual-2017

Papert, S. (1984). New theories for new learnings. School Psychology Review, 13(4), 422-428. https://doi.org/10.1080/02796015.1984. 12085122

Publisher's Note Springer Nature remains neutral with regard to jurisdictional claims in published maps and institutional affiliations. 